\title{
Colonization and growth dynamics of three species of Fucus
}

\author{
M. Keser* and B. R. Larson** \\ Department of Botany and Plant Pathology, University of Maine, Orono, Maine 04473, USA
}

\begin{abstract}
Colonization, growth and mortality of Fucus vesiculosus L., $F$. vesiculosus L. var. spiralis Farl. and F. distichus L. subsp. edentatus (Pyl.) Powell were investigated from August 1973 to April 1976. Grazing by Littorina littorea L. retarded but did not prevent colonization of Fucus. Growth of Fucus spp. was characterized by high variability both within and among sites. The general growth pattern consisted of slow to moderate growth during winter and early spring and rapid growth throughout summer and autumn. Growth was inversely proportional to intertidal height. Removing Ascophyllum nodosum (L.) Le Jol, and Chondrus crispus Stackh., from protected rocky shores permitted colonization and development of $F$. vesiculosus throughout the intertidal region. Following colonization, the mortality of $F$. vesiculosus germlings was high. Such losses were not reflected in areal cover measurements, however, because of the continued growth of surviving thalli. Mortality of large plants occurred mainly during winter, owing to ice and storm damage. This mortality, as well as a reduced growth rate, was responsible for the slow increase in algal cover during winter.
\end{abstract}

\section{INTRODUCTION}

Several Fucus species and Ascophyllum nodosum (L.) Le Jol. are the dominant intertidal algae along Maine's rocky coastline (Kemp, 1862; Johnson and Skutch, 1928a, b; Taylor, 1957; Vadas et al., 1976; Topinka et al., 1981). A. nodosum dominates sheltered areas of the open coast but is gradually replaced by Fucus spp. as exposure increases. In Maine estuaries, $F$. vesiculosus L. and $F$, vesiculosus L. var. spiralis Farl. are limited to small patches within the broad cover of $A$. nodosum and to the upper and lower fringes of the A. nodosum zone (Vadas et al., 1976). F. vesiculosus becomes more dominant as exposure increases to moderate levels (Keser et al., 1981; Topinka et al., 1981); but $F$ vesiculosus var. spiralis is restricted to the estuaries. Similar fucoid distribution and abundance patterns have been observed in New England (Lamb and Zimmermann, 1964; Mathieson et al., 1981; Mathieson and Hehre, 1982), Canada (MacFarlane, 1953; Berard-Therriault and Cardinal, 1973), Norway (Baardseth, 1955, 1958), Sweden (Aleem, 1969), Ice-

\footnotetext{
Present addresses:

- NU Environmental Laboratory, P.O. Box 128, Waterford, Connecticut 06385, USA

- Marine Colloids Division, FMC Corporation, Rockland, Maine 04841, USA
}

land (Munda, 1964), and in the British Isles (David, 1943; Walker, 1947; Knight and Parke, 1950; Schonbeck and Norton, 1978). More exposed habitats in Maine are dominated by $F$. distichus L. subsp. edentatus (Pyl.) Powell (Keser, 1978). The studies of Powell (1963) represent the best taxonomic review of the systematics and world wide distribution of the genus.

The present study examines the colonization, growth and mortality of Fucus vesiculosus, $F$. vesiculosus var. spiralis, and $F$. distichus subsp. edentatus in Maine. It also includes data from a large number of plants from a population of known age structure. The extended period of the study (1973-1976) allows assessment of seasonal and yearly variability.

\section{MATERIAL AND METHODS}

Five study sites were designated in August 1973 (Fig. 1). Fucus vesiculosus was studied at 2 estuarine sites (Ferry Site and Foxbird Island in Montsweag Bay), and at a moderately exposed site (Pemaquid Point-Sheltered). Another sheltered estuarine site (Bennett Neck in Damariscotta River) was used to study a form of $F$. vesiculosus which has been attributed by previous authors (e.g. Taylor, 1957; Mathieson et al., 1981) to var. spiralis Farlow. The 


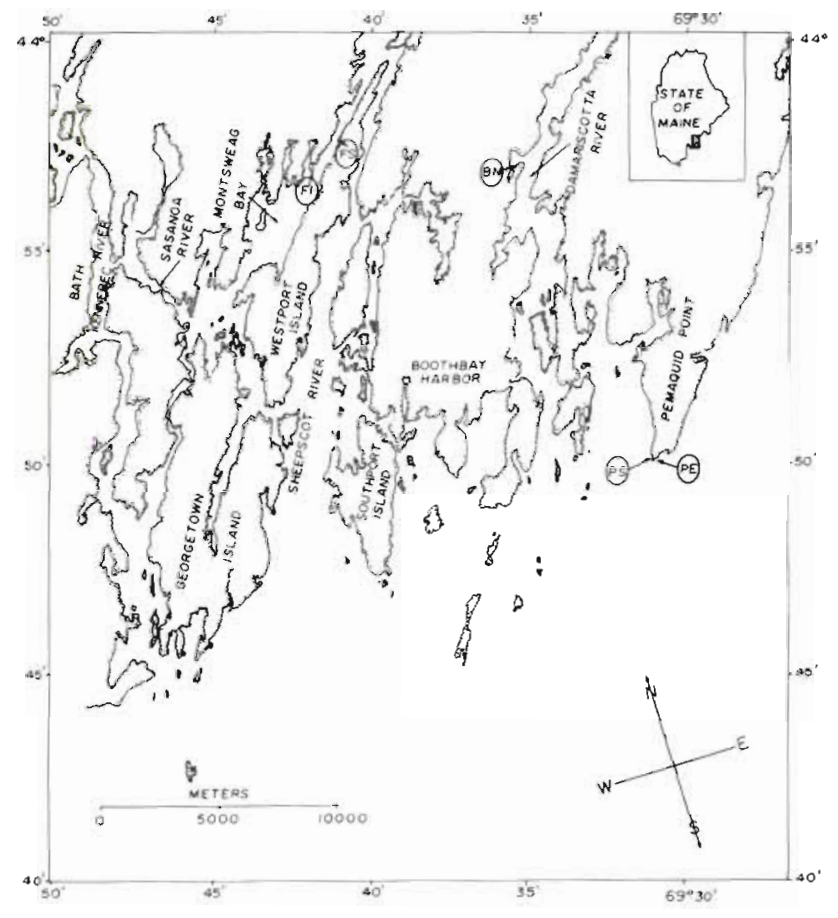

Fig. 1. Location of sampling stations. FI Foxbird Island; FS Ferry Site; BN Bennett Neck; PE Pemaquid Point-Exposed; PS Pemaquid Point-Sheltered

taxonomic status of this form needs investigation, but our data indicate a degree of distinctness, whether genotypic or phenotypic. $F$. distichus subsp. edentatus was studied at Pemaquid Point-Exposed, an exposed site $400 \mathrm{~m}$ south-southeast from Pemaquid Point-Sheltered.

Prior to the experiment, substrata at Ferry Site, Foxbird Island, and Bennett Neck were dominated by Ascophyllum nodosum (78 to $92 \%$ of wet weight biomass). At Pemaquid Point-Sheltered, Ascophyllum accounted for $47 \%$ of the algal biomass, Fucus vesiculosus 33\%, Chondrus crispus Stackh. 14\%, and Polysiphonia lanosa (L.) Tandy 6\%; barnacles were also common. Ascophyllum was absent from Pemaquid Point-Exposed; there, Fucus spp. accounted for almost $100 \%$ of the algal biomass, but only $20 \%$ of the substratum coverage $(50 \%$ was barnacles, $15 \%$ mussels, the remainder bare rock and ephemeral algae).

Three permanently marked strips of rocky shore (granitic and basaltic ledges), perpendicular to the waterline, were scraped clean and burned with a propane torch at each of the 5 sites in August 1973. Each strip was $0.5 \mathrm{~m}$ wide and extended from mean high water (MHW) to mean low water (MLW) levels. Three additional strips were cleared and burned at each site in winter (December 1973 or January 1974) and in spring (June 1974) to study seasonal effects on colonization. To assess yearly variability and to replicate the previous summer's denudings, 3 additional strips were denuded at each site in August 1974.

The denuded strips were divided into 3 zones representing upper (Zone I), middle (Zone II), and low intertidal (Zone III) regions; the vertical tidal range averaged $2.7 \mathrm{~m}$. Depending upon substratum slope at each site, the designated intertidal zones contained 3 to 9 quadrats (replicates), each measuring $0.5 \times 1.0 \mathrm{~m}$. The percentage of substratum coverage was estimated for each species in each quadrat. Owing to their phenotypic plasticity (Powell, 1957, 1963), specific identification of Fucus germlings was impossible; they were recorded as Fucus sp. Length measurements of the germlings were made monthly until subsequent development enabled specific identification; further growth was measured seasonally.

Plant lengths were determined from holdfast to tip of the longest branch. Length increases were expressed as mean increase in $\mathrm{mm} \mathrm{mo}^{-1}$, obtained by dividing the length increase by time between consecutive sampling dates. Twenty Fucus plants quadrat ${ }^{-1}$ were measured at each site during each census (therefore, because of differences in slope noted above, each zone was represented by 60 to 180 plants).

Grazer exclusion cages were placed at Bennett Neck in one of the strips denuded in June 1974 to determine the influence of grazing by Littorina littorea $\mathrm{L}$. on the colonization and subsequent growth of Fucus vesiculosus var, spiralis. A single cage and control area were located in each intertidal zone and a cover (cage with open sides) was placed in Zone III. Exclusion cages measured $20 \times 20 \times 5 \mathrm{~cm}$, and were constructed of stainless steel (mesh size $3 \times 3 \mathrm{~mm}$ ); each cage was fastened to the substratum with 4 stainless steel screws

Plant density of Fucus vesiculosus at Ferry Site was determined by counting germlings that colonized Zone III of the strips denuded in August 1974. Plants were counted in 10 randomly placed subquadrats (each $5 \times 5 \mathrm{~cm}$ ); counts were averaged and converted to number of plants $\mathrm{m}^{-2}$. Detailed descriptions of the sites and environment (salinity, temperature, light, and extinction coefficients) have been given by Vadas et al. (1976, 1978), Keser (1978), and Keser et al. (1981).

\section{RESULTS}

\section{Fucus vesiculosus at Ferry Site, Foxbird Island, and Pemaquid Point-Sheltered}

Fucus vesiculosus was the only species of Fucus to recover at these sites, and the time needed to colonize most denuded substrata ranged from 3 to 21 mo at Ferry Site, 4 to 9 mo at Foxbird Island, and 4 to $12 \mathrm{mo}$ at 

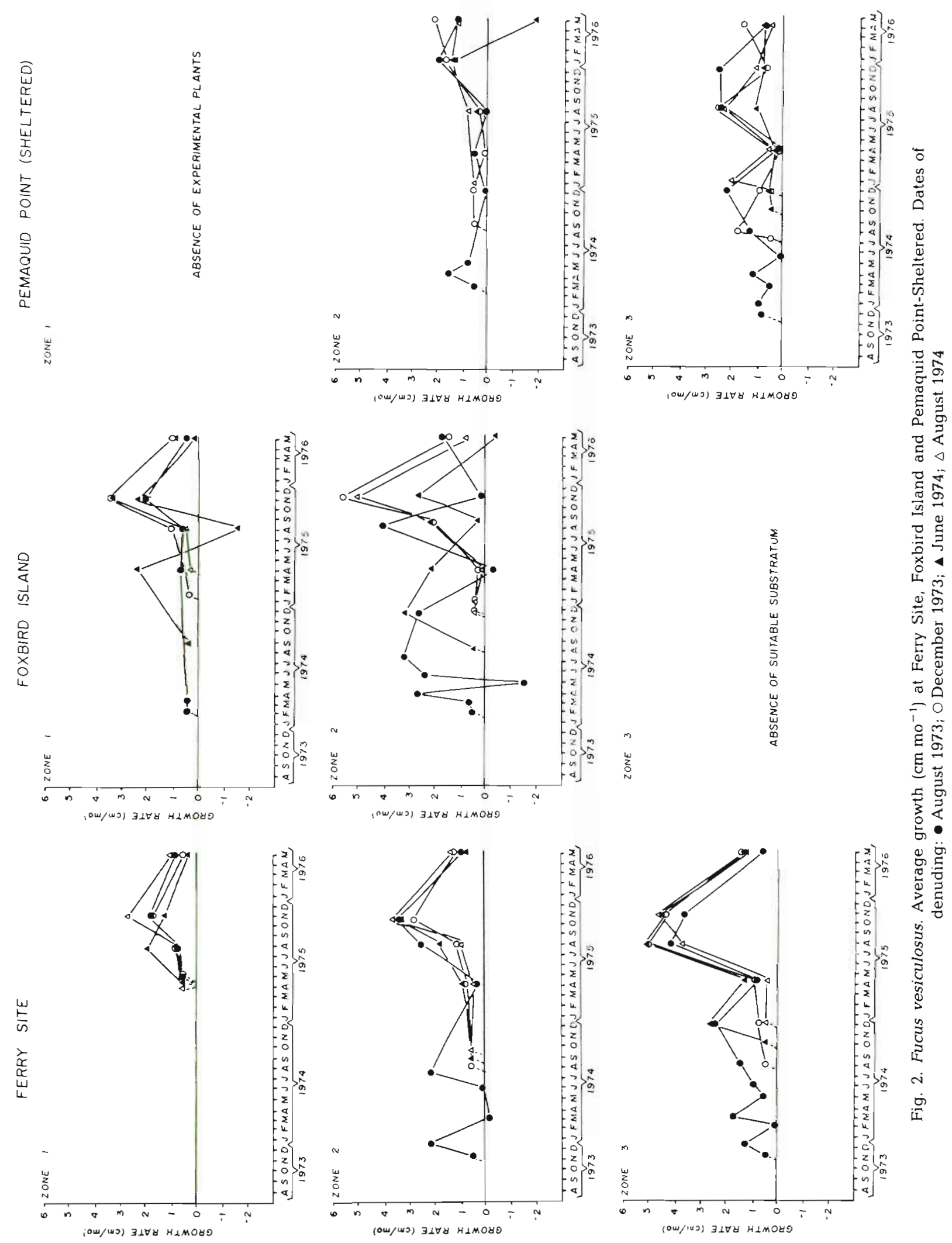
Table 1. Fucus vesiculosus. Variability in length $(\mathrm{mm})$ in Zone III at Ferry Site (based on 6 quadrats denuded in August 1973). Each mean based on measurements of 20 plants

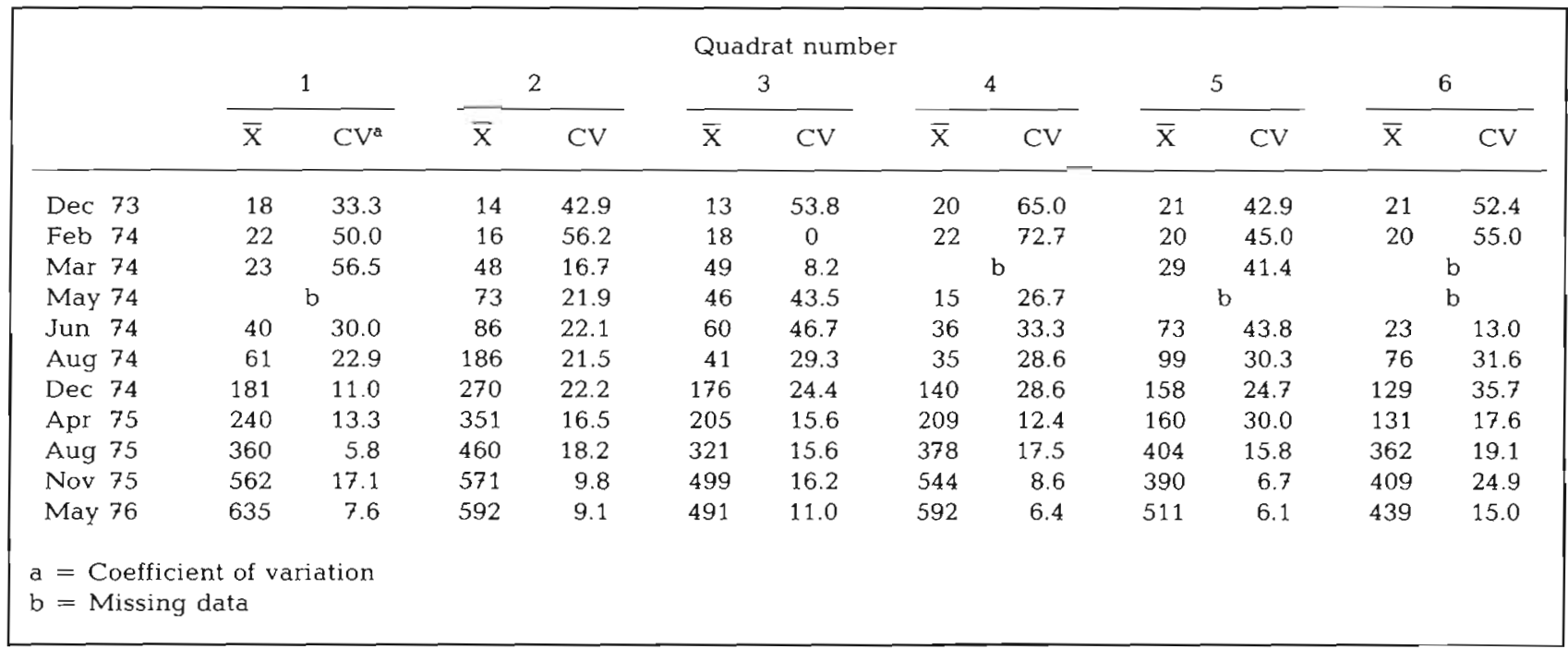

Pemaquid Point-Sheltered (Fig. 2). Zone I at Pemaquid Point-Sheltered had not been colonized by the end of the experiment (May 1976; 33 mo after the first denuding). Zone III at Foxbird Island was a mudflat, with no substratum suitable for denuding or colonization by Fucus. Rates of colonization and subsequent growth were inversely related to intertidal height, i.e. fastest in Zone III and slowest in Zone I. Settlement of $F$. vesiculosus in Zones II and III, at Ferry Site and Foxbird Island, occurred in late summer or autumn regardless of the time of denuding. Colonization at Pemaquid Point-Sheltered appeared to be random, and was not closely related to either time of year or time since denuding. Zone I of most strips denuded at different seasons were colonized by $F$. vesiculosus in late winter-early spring.

Table 2. Growth, as increase in percent cover, of: Fucus vesiculosus at Ferry Site, Foxbird Island, and Pemaquid Point-Sheltered; $F$. vesiculosus var. spiralis at Bennett Neck $F$. distichus subsp. edentatus at Pemaquid Point-Exposed

\begin{tabular}{|c|c|c|c|c|c|c|c|c|c|c|c|c|}
\hline & \multicolumn{3}{|c|}{ August 73} & \multicolumn{3}{|c|}{ December 73} & \multicolumn{3}{|c|}{ June 74} & \multicolumn{3}{|c|}{ August 74} \\
\hline & $\mathrm{ZI}$ & ZII & ZIII & $\mathrm{ZI}$ & ZII & ZIII & $\mathrm{ZI}$ & ZII & ZIII & $\mathrm{ZI}$ & ZII & ZIII \\
\hline \multicolumn{13}{|c|}{ Ferry Site } \\
\hline May 74 & 0 & 0 & 1 & 0 & 0 & 0 & - & - & - & - & - & - \\
\hline May 75 & 1 & 20 & 68 & 2 & 10 & 68 & 1 & 8 & 55 & 2 & 10 & 57 \\
\hline May 76 & 25 & 95 & 92 & 25 & 85 & 84 & 40 & 95 & 88 & 54 & 95 & 81 \\
\hline \multicolumn{13}{|c|}{ Foxbird Island } \\
\hline May 74 & 1 & 3 & & 0 & 0 & & - & - & & - & - & \\
\hline May 75 & 16 & 92 & & 7 & 14 & & 1 & 11 & & 1 & 6 & \\
\hline May 76 & 71 & 65 & & 38 & 61 & & 53 & 79 & & 32 & 79 & \\
\hline \multicolumn{13}{|c|}{ Pemaquid Point - Sheltered } \\
\hline May 74 & 0 & 0 & 4 & 0 & 0 & 0 & - & - & - & - & - & - \\
\hline May 75 & 0 & 2 & 43 & 0 & 2 & 28 & 0 & 0 & 1 & 0 & 1 & 5 \\
\hline May 76 & 0 & 13 & 49 & 0 & 9 & 49 & 0 & 0 & 17 & 0 & 28 & 43 \\
\hline \multicolumn{13}{|c|}{ Bennett Neck } \\
\hline May 74 & 0 & 0 & 0 & 0 & 0 & 0 & - & - & - & - & - & - \\
\hline May 75 & 1 & 5 & 15 & 2 & 6 & 14 & 1 & 2 & 6 & 0 & 1 & 2 \\
\hline Apr 76 & 3 & 27 & 52 & 9 & 30 & 51 & 1 & 28 & 40 & 9 & 21 & 24 \\
\hline \multicolumn{13}{|c|}{ Pemaquid Point - Exposed } \\
\hline Apr 74 & 0 & 0 & 0 & 0 & 0 & 0 & - & - & - & - & - & - \\
\hline May 75 & 2 & 4 & 29 & 1 & 6 & 24 & 0 & 1 & 5 & 0 & 0 & 0 \\
\hline May 76 & 8 & 13 & 51 & 6 & 20 & 54 & 12 & 32 & 63 & 1 & 1 & 4 \\
\hline
\end{tabular}


Maximum growth ranged from ca. $3.5 \mathrm{~cm} \mathrm{mo}^{-1}$ at Ferry Site, 4.0 to $6.0 \mathrm{~cm} \mathrm{mo}^{-1}$ at Foxbird Island, 2.0 to $2.5 \mathrm{~cm} \mathrm{mo}^{-1}$ at Pemaquid Point-Sheltered. Growth was generally fastest in late summer and autumn, and slowest in winter and spring. Decreases in average length were attributed to plant mortality and breakage, especially during winter and early spring storms.

Growth was variable among quadrats in the same zone, and even among plants within the same quadrat. As a representative example, Table 1 presents average lengths of 20 plants in each of 6 quadrats from Zone III of the August 1973 denuding at Ferry Site. An analysis of variance performed on square-root transformed data from May 1976 showed that differences in length between quadrats were highly significant ( $p<0.01$ ), even though the plants had colonized at the same time.

The inverse relationship of intertidal height to rates of colonization and growth was also evidenced by percent cover measurements. Table 2 summarizes growth data (increase in percent cover) for up to $3 \mathrm{yr}$; values for each sampling time are presented in Keser (1978). The percent cover of Fucus vesiculosus increased with time, and was generally greatest in Zone III; however, coverage varied both within and among stations, and values at the end of the experiment did not necessarily correspond to the time since initial colonization. Partial or total thallus loss could cause a decrease cover from one sampling period to the next, especially in Zone III.
Density patterns of Fucus vesiculosus predictably showed an inverse relationship with time. At Ferry Site, densities following the August 1974 denuding averaged 43,600 plants $\mathrm{m}^{-2}$ in April 1975 (Fig. 3). Subsequently, densities declined to 3,880 plants $\mathrm{m}^{-2}$ in November 1975, to 2,240 plants $\mathrm{m}^{-2}$ in May 1976, and to 480 plants $\mathrm{m}^{-2}$ in April 1977. Despite the loss of over $90 \%$ of the plants between April and November 1975 , percent coverage increased from 32 to $94 \%$ over the same period, owing to continued growth of surviving individuals. However, subsequent mortality reduced coverage to $81 \%$ by May 1976 and $18 \%$ by April 1977 ; concurrently, the average plant length decreased. By the end of the experiment, only holdfasts and midrib stumps of the original plants remained.

\section{Fucus vesiculosus var. spiralis at Bennett Neck}

Substrata denuded at Bennett Neck were colonized by Fucus vesiculosus var. spiralis within 3 to $13 \mathrm{mo}$ after denudation (Fig. 4), and no other form of Fucus was found during the experiment. The same general trend of more rapid colonization and growth with decreased intertidal height was evident, but to a lesser degree than noted for $F$. vesiculosus. Regardless of denudation time, the patterns of colonization were similar. Plants first appeared in crevices and later on smooth surfaces. Once germlings were established,

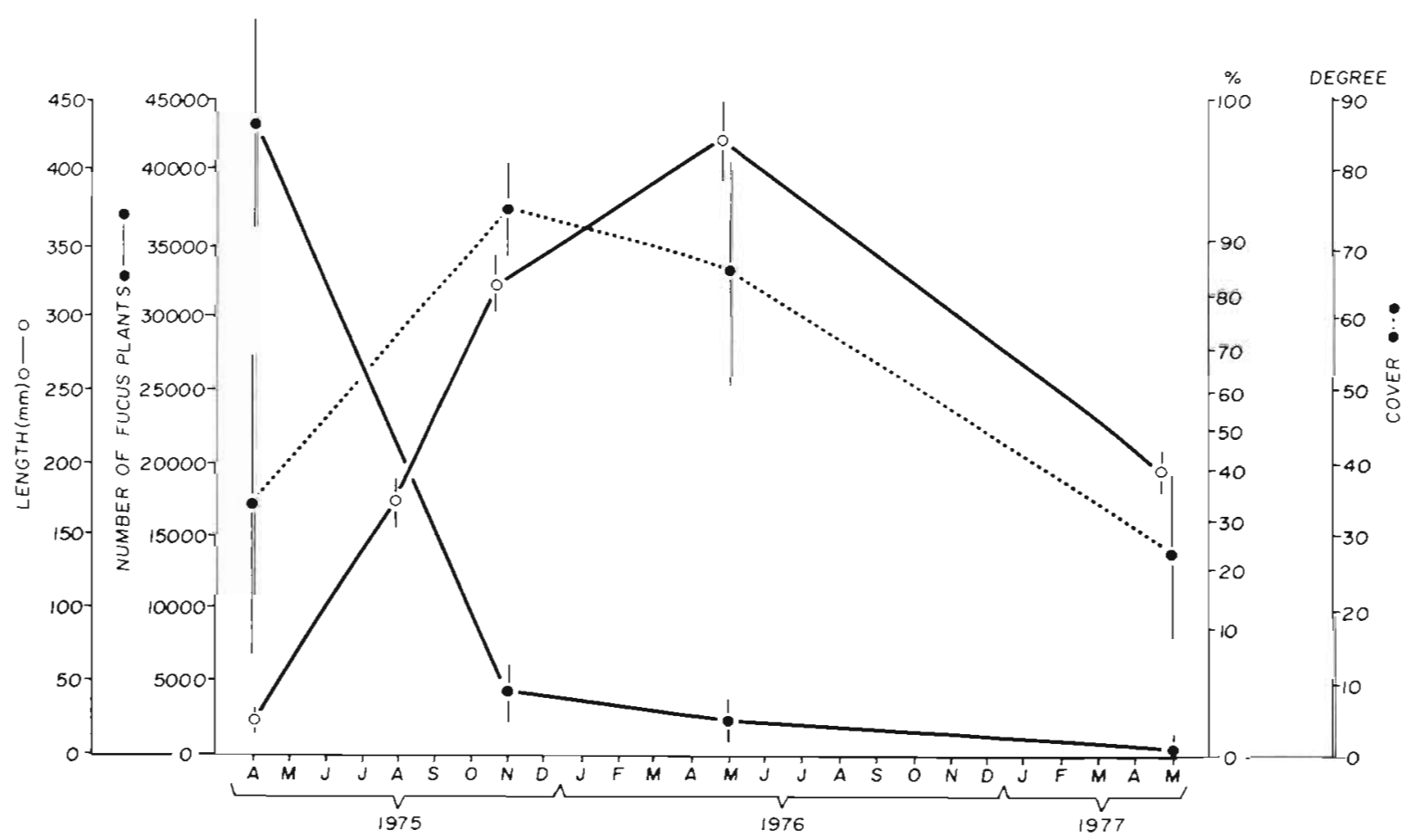

Fig. 3. Fucus vesiculosus. Density, length, and percent cover in Zone III at Ferry Site, following August 1974 denuding. Bars: $95 \%$ confidence intervals. Percent cover data were transformed with the angular transformation 
cover increased continuously in Zones II and III (but not in Zone I). At the conclusion of the study, coverage by $F$. vesiculosus var. spiralis ranged from 1 to $52 \%$ (Table 2), and was highest in Zone III. Mean growth ranged from 0.3 to $1.0 \mathrm{~cm} \mathrm{mo}^{-1}$.

The same trend of rapid growth of established germlings was evident from the grazer exclusion study (Table 3). The cages provided a more effective refuge for Fucus germlings than did crevices. In Zone I, neither caged nor control areas were appreciably colonized $(\leq 2 \%)$. In Zones II and III, Fucus covered 70
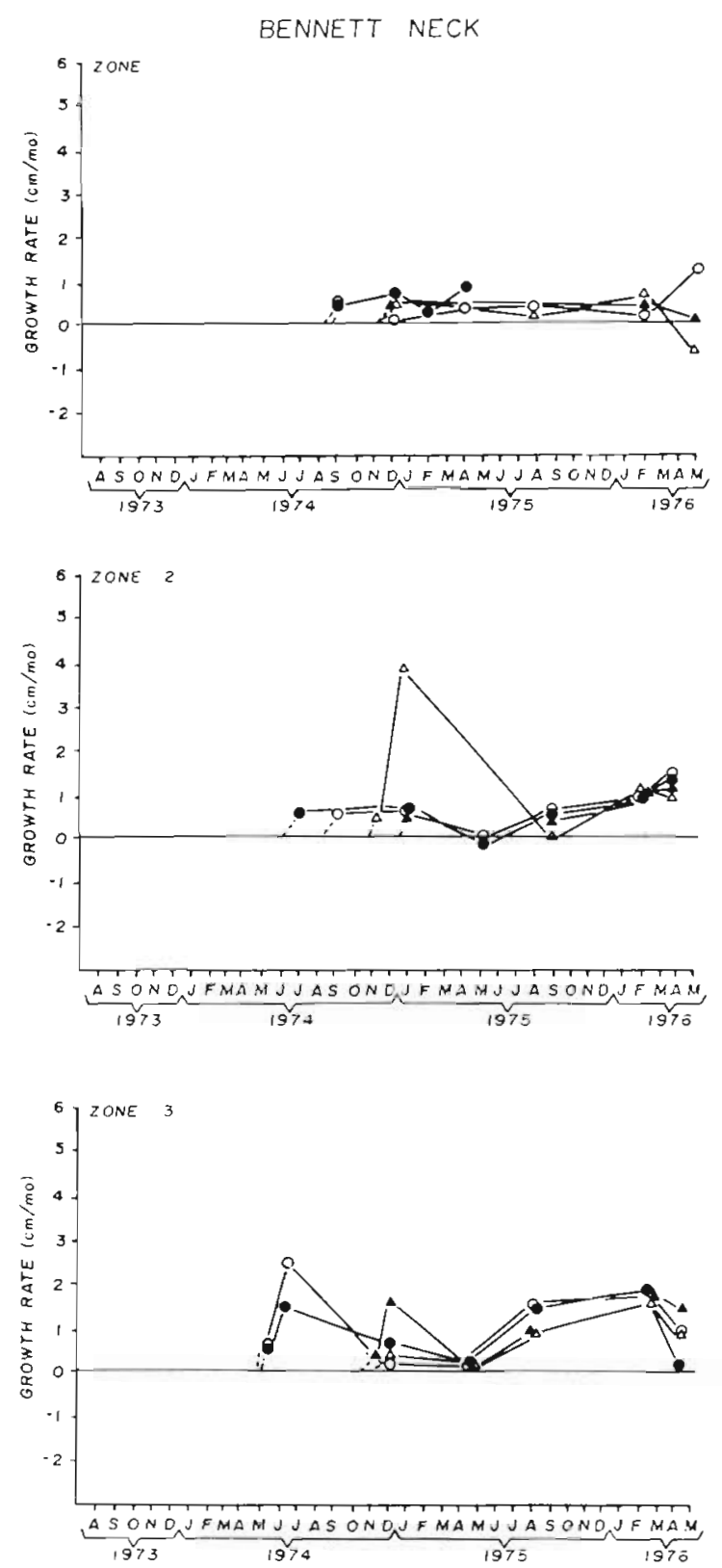

and $50 \%$, respectively, of the caged area after $7 \mathrm{mo}$ and plants averaged $2.2 \mathrm{~cm}$ in length. In the same period, $F$. vesiculosus var. spiralis covered less than $2 \%$ of the control areas. In order to test effect of cages on Fucus growth, cages were removed in March 1975. Coverage increased to $100 \%$ within $1 \mathrm{yr}$, due to continued growth of existing plants. Coverage of the control areas also increased, but more slowly. The percent cover of Fucus in the area under the open sided cage in Zone III was virtually the same as in the uncaged control area throughout the study.
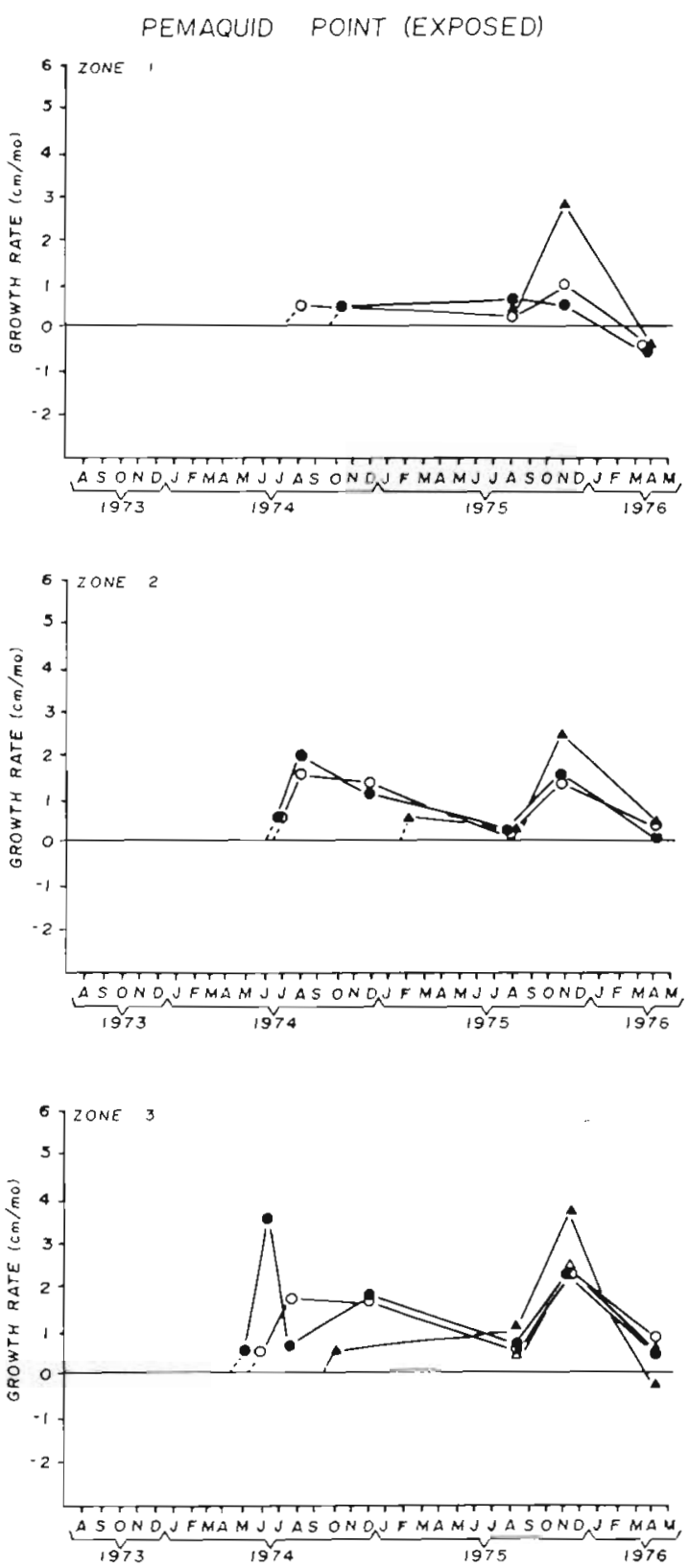

Fig. 4. Average growth ( $\mathrm{cm} \mathrm{mo} \mathrm{mo}^{-1}$ ) of Fucus vesiculosus var. spiralis at Bennett Neck and F. distichus ssp. edentatus at Pemaquid Point-Exposed. Dates of denuding: - August 1973; O January 1974; $\wedge$ June 1974; $\triangle$ August 1974 
Table 3. Fucus vesiculosus var, spiralis. Percent cover at Bennett Neck

\begin{tabular}{|c|c|c|c|c|c|c|c|}
\hline & \multicolumn{2}{|c|}{ Zone I } & \multicolumn{2}{|c|}{ Zone II } & \multicolumn{2}{|c|}{ Zone III } & \multirow[b]{2}{*}{$E(c)$} \\
\hline & E & $\mathrm{C}$ & $E$ & C & $\mathrm{E}$ & C & \\
\hline Jun 74 & \multicolumn{7}{|c|}{ Areas denuded at this time } \\
\hline \multicolumn{8}{|l|}{ Jul 74} \\
\hline \multicolumn{8}{|l|}{ Aug 74} \\
\hline \multicolumn{8}{|l|}{ Sep 74} \\
\hline Nov 74 & & & 55 & & 10 & & \\
\hline Dec 74 & & 1 & 75 & 1 & 25 & 1 & 1 \\
\hline Jan 75 & & 1 & 75 & 1 & 55 & 2 & 2 \\
\hline - Mar 75 & & 1 & 70 & 1 & 50 & 1 & 1 \\
\hline Apr 75 & & 1 & 83 & 1 & 18 & 3 & 2 \\
\hline May 75 & & 1 & 92 & 2 & 25 & 6 & 4 \\
\hline Aug 75 & & & 98 & 8 & 78 & 14 & 10 \\
\hline Feb 76 & 1 & 2 & 96 & 27 & 100 & 37 & 35 \\
\hline Apr 76 & 1 & 2 & 100 & 28 & 100 & 40 & 45 \\
\hline \multicolumn{8}{|c|}{ E Experimental (complete exclusion cage) } \\
\hline \multicolumn{8}{|c|}{ C Control (No cover) } \\
\hline \multicolumn{8}{|c|}{ E(c) Experimental (cage without sides) } \\
\hline - Cages & mo & $M c$ & h 16 , & 975 & & & \\
\hline
\end{tabular}

\section{Fucus distichus subsp. edentatus at Pemaquid Point- Exposed}

Colonization of denuded substrata at Pemaquid Point-Exposed by Fucus was accomplished exclusively by $F$. distichus subsp. edentatus (hereafter referred to as $F . d$. edentatus). This occurred as soon as 4 mo after denuding, but in some cases had not occurred by the end of the experiment (21 mo after denuding, Fig. 4). In most cases, $F$. d. edentatus first appeared in late summer or autumn. Growth was variable between zones, seasons, and strips denuded at different times. Maximum values ranged from ca. 2.5 to $4.0 \mathrm{~cm} \mathrm{mo}^{-1}$, and usually occurred in autumn.

The percent cover of Fucus d. edentatus was also inversely related to intertidal height (Tab. 2); values generally increased gradually following colonization, but declined during winter (Keser, 1978). At the conclusion of the study, the percent coverage of the areas denuded in August 1973, January 1974, and June 1974 ranged from 6 to $12 \%$ in Zone I, 13 to $32 \%$ in Zone II, and 51 to $63 \%$ in Zone III (Tab. 2). The lowest coverage by $F$. d. edentatus resulted from the August 1974 denuding $(1 \%, 1 \%$, and $4 \%$ in Zones I, II, and III, respectively).

\section{DISCUSSION}

Fucus was the first perennial alga to colonize the experimentally denuded transects, even at sites and tidal levels that had been initially dominated by Ascophyllum or Chondrus. Absence of Ascophyllum plants following experimental or natural substratum denudation has been reported (Knight and Parke, 1950; Printz, 1956, 1959; Baardseth, 1970; Sundene, 1973). Lubchenco (1980) showed that removal of Chondrus from low intertidal permitted dense settlement of Fucus.

In this study Fucus colonization was usually preceded by the establishment of populations of ephemeral algae (e.g. Porphyra umbilicalis, Enteromorpha spp., Ulothrix flacca, Bangia atropurpurea, or diatoms), or of barnacles (Balanus balanoides L.). A similar pattern was observed at rocky shores in West Cornwall following the 'Torrey Canyon' oil spill (Southward and Southward, 1978; Southward, 1979). The presence of barnacles or ephemeral algal was not prerequiste for Fucus colonization. Sometimes, Fucus initiated colonization on denuded substrata.

On the basis of the present study, we can only infer periodicity of gamete release from the appearance of Fucus germlings. Newly settled germlings of $F$, vesiculosus were found in most months, indicating a broad period of reproductivity. European populations of $F$. vesiculosus also show long reproductive periods (Knight and Parke, 1950; Printz, 1959). F. vesiculosus var. spiralis and $F$. $d$. edentatus settled over a shorter period (May-December), perhaps reflecting a narrower period of reproductive activity. Maximum reproduction for $F$. vesiculosus var. spiralis in New Hampshire (USA) occurred from March-June, but fertile plants were found throughout the year (at least in some years; Mathieson et al., 1976).

Colonization by Fucus spp. occurred earliest in the low intertidal zone, and subsequent growth was fastest in this zone (cf. Lubchenco, 1980). Slower colonization and growth in Zone I (and occasional failure to colonize, e.g. at Pemaquid Point-Sheltered) was in part due to grazing by Littorina littorea, which has seldom been reported to be important in the high intertidal. Studies in Connecticut, USA, indicate that L. littorea may be seasonally abundant in high intertidal areas, and that its feeding activities may exert considerable influence on upper intertidal communities (NUSCo 1981).

The absence of Fucus from Pemaquid Point-Exposed following the August 1974 denuding appeared to result from interspecific competition for substratum. Porphyra umbilicalis (L.) J. Ag, and Enteromorpha spp. appeared in all 3 zones within a month following denudation; Porphyra quickly dominated, and accounted for almost $100 \%$ of the coverage by the following spring. The alga continued to dominate all 3 strips denuded in August 1974 (but not the 9 strips denuded earlier), although coverage values decreased somewhat. F. distichus subsp. edentatus appeared in these strips for the first time in November 1975, and at 
the conclusion of the experiment (April 1976), was still scarce. Southward and Southward (1978) also reported delay in Fucus colonization following prolonged 'greening' by ephemeral algae at some of their sites.

The above discussion, as well as the wide discrepancies in colonization times (even when denudings were established in the same month of successive years), illustrates the variability associated with Fucus colonization within and among stations, and between years. This implies that colonization in intertidal areas may be determined more by stochastic events, or random selection from possible alternatives, than from specific successional sequences.

The growth of Fucus has generally been measured as linear increase (Knight and Parke, 1950), but increases in thickness, lateral growth, and dichotomies are produced concurrently and are also growth indicators (Lund, 1936). Some of these parameters are closely correlated to linear increases. For example, the number of dichotomies is proportional to plant length (Knight and Parke, 1950; Subrahmanyan, 1961). In searching for additional criteria to assess Fucus growth, Knight and Parke (1950) recognized the futility of attempting to relate the number of frond apices to growth because of extensive frond mortality in the field.

Similarly, we found the number of dichotomies inadequate to assess Fucus growth, and increase in percent cover was a more representative parameter. Biomass measurements were not made, because these samples were part of a long-term, non-destructive successional study. However, other studies of $F$. vesiculosus in Maine have shown biomass to be highly variable among and within sites, and between years at the same site (Keser, 1978; Keser et al., 1981; Topinka et al., 1981).

Growth patterns were similar for all Fucus spp. studied, using both linear increase and percent cover increase. Growth was low in winter, increased in spring, stabilized through summer, and reached maxima in autumn (Fig. 2 and 4). During the winter, increased plant mortality (partial or total) resulted in decreased average length and percent cover.

The observation that Fucus colonization occurred earliest in the low intertidal may be a simple function of the length of time available for settling. Since submergence time is inversely related to intertidal height, fertilized eggs in the water column have a better chance of settling on suitable substrata in the low intertidal. Baker (1910) found that the greatest development of germlings, including those of $F$. vesiculosus, occurred under a desiccation regime that simulated low intertidal conditions, i.e. $11 \mathrm{~h}$ immersed and $1 \mathrm{~h}$ emersed. Lubchenco (1980) reported that $F$. vesiculosus and $F$. $d$. edentatus grew better in low- than in mid-shore zones, although they were excluded from the low intertidal by competition from Chondrus crispus.

Comparison of our results to those of other researchers is difficult. Most investigators did not report the number of plants studied or intertidal elevation. Also, growth determinations varied from measuring growth of old plants (Printz, 1959) to growth of newly colonized individuals (Knight and Parke, 1950). Many studies failed to describe degree of exposure to waves and water movement, others were of too short a duration to assess temporal variability (Hariot, 1909; Lemoine, 1913; Gislen, 1930; Hatton, 1932; Burrows, 1956). The few long-term studies (Nienburg, 1930; Moore, 1939), as well as ours, emphasize the variability of seasonal and yearly growth.

Despite the problems of different approaches to the assessment of Fucus growth, some comparisons can be made. Converting our growth to yearly averages, our growth for $F$. vesiculosus in Maine (15 to $21 \mathrm{~mm} \mathrm{mo}^{-1}$ ) is slightly less than that reported from Canada (16 to 32 $\mathrm{mm} \mathrm{mo}^{-1}$; Breton-Provencher et al., 1979). Our values are approximately midway in the range reported from Europe; 6 to $10 \mathrm{~mm} \mathrm{mo}^{-1}$ in Norway (Printz, 1959), 10 to $28 \mathrm{~mm} \mathrm{mo}^{-1}$ in Great Britain (Knight and Parke, 1950), and 25 to $33 \mathrm{~mm} \mathrm{mo}^{-1}$ in France (Lemoine, 1913).

The growth of Fucus vesiculosus var. spiralis in Maine ranged from 3 to $20 \mathrm{~mm} \mathrm{mo}^{-1}$; these values are lower than reported for New Hampshire $\left(23 \mathrm{~mm} \mathrm{mo}^{-1}\right.$; Mathieson et al., 1976) and for Long Island, New York (21 to $32 \mathrm{~mm} \mathrm{mo}^{-1}$; Brinkhuis, 1975), but differences in methodology may explain some of the discrepancies. Our values for $F$. d. edentatus ( 6 to $10 \mathrm{~mm} \mathrm{mo}^{-1}$ ) are also lower than those reported for Canada (16 to 23 mim mo ${ }^{-1}$, Breton-Provencher et al., 1979).

The longevity of Fucus vesiculosus and $F$ vesiculosus var. spiralis ranged from 2 to $4 \mathrm{yr}$ at the estuarine site, and slightly less at the more exposed site on Pemaquid Point. The oldest individuals of $F . d$. edentatus in the experimental strips at Pemaquid Point-Exposed were 2 ys old in the spring of 1976, when extensive mortality occurred, associated with heavy growth of epiphytes. Similar age distributions for Fucus spp. have been reported by others (Nienburg, 1930; Rees, 1932; Knight and Parke, 1950; Niemeck and Mathieson, 1976).

At some sites, the loss of germlings and young Fucus plants was related to grazing activity. For example, Littorina littorea was present throughout the year at Pemaquid Point-Sheltered and Bennett Neck. Seasonally, snails were most abundant in spring and autumn, at times exceeding 200 snails $\mathrm{m}^{-2}$. When snails were excluded by cages following denuding, as at Bennett Neck, Fucus colonization occurred sooner and subse- 
quent growth was more rapid (Tab. 3). Similar results were obtained in Connecticut (NUSCo, 1981) and, similarly, the removal of limpets from the shore in England increased the density of fucoids (Jones, 1948; Lodge, 1948; Southward, 1953, 1956, 1964; Boney, 1965).

Snails could also be excluded from the study areas by unfavorable environmental conditions. Littorina littorea was rare at Foxbird Island and Ferry Site, most likely a result of large fluctuations in salinity (10 to $20 \%$ ), and at Pemaquid Point-Exposed, due to high wave exposure. Therefore, the observed mortality of young Fucus germlings at these sites could not be attributed to grazing. At Ferry Site, for instance, the loss of $F$. vesiculosus germlings was most likely caused by competition for light and space (Fig. 3). There simply was not enough substratum available to support the extremely high initial densities of germlings $(>$ $43,000 \mathrm{~m}^{-2}$ ). Large germling mortality due to intraspecific competition was also noted by Knight and Parke (1950) and by Subrahmanyan (1961).

Grazing was not considered to be a major source of mortality for mature plants at any site (cf. Lubchenco, 1978; Keser, 1978); rather, loss was due to extrinsic physical factors (e.g. winter storms and ice scouring).

Acknowledgements. We owe thanks to R. L. Vadas, L. J. Laber, B. J. McAlice, B. H. Brinkhuis, R. T. Wilce, J. F. Foertch and A. C. Mathieson for critical comments on the manuscript, and to A. J. Southward and 2 anonymous referees for helpful suggestions. Thanks to P. C. Rusanowski for help in initial stages of this study. These studies were supported, in part, by Hatch Project No. 295 and the Maine Yankee Atomic Power Co. (Contribution 150, Ira C. Darling Center, University of Maine, Walpole, ME)

\section{LITERATURE CITED}

Aleem, A. A. (1969). Zonation, vesicle pressure and gas composition in Fucus vesiculosus and Ascophyllum nodosum at Kristineberg (West Coast of Sweden). Mar. Biol. 4: $36-43$

Baardseth, E. (1955). A statistical study of the structure of the Ascophyllum zone. Norw. Inst. Seaweed Res., Rep. 11; $1-34$

Baardseth, E. (1958). The quantitative composition of the fucoid zone. Norw. Inst. Seaweed Res., Rep. 20:7-10

Baardseth, E. (1970). Synopsis of biological data on knobbed wrack Ascophyllum nodosum (Linnaeus) LeJolis. F.A.O. Fish. Synopses 38, Rev. 1

Baker, S. M. (1910). On the causes of the zoning of brown seaweeds on the seashore. II. The effect of periodic exposure on the expulsion of gametes and on the germination of the oospore. New Phytol. 9: 54-67

Berard-Therriault, L., Cardinal, A. (1973). Importance de certains facteurs ecologiques sur la resistance a la dessication des Fucacees (Phaeophyceae). Phycologia 12: 41-52

Boney, A. D. (1965). Aspects of the biology of the seaweeds of economic importance. In: Russell, F. S. (ed.) Advances of marine biology, Vol. 3, p. 105-253
Breton-Provencher, M., Gagne, J. A., Cardinal, A. (1979). Estimation de la production des algues benthiques mediolittorales dans l'estuaire maritime du Saint-Laurent (Quebec). Can. Nat. 106: 199-209

Brinkhuis, B. H. (1975). Seasonal variations in macroalgae productivity in a temperate salt-marsh. Ph. D. Dissertation, State University of New York at Stony Brook, New York

Burrows, E. M. (1956). Growth control in the Fucaceae. Proceedings of the International Seaweed Symposium, Vol. 2, p. $163-170$

David, H. M. (1943). Studies in the autecology of Ascophyllum nodosum Le Jol. J. Ecol. 31: 178-199

Gislen, T. (1930). Epibioses of the Gullmar Fjord. Pt. 2. Marine sociology. Kristinebergs zool. stat., 1877-1927. Skrifter Serie J. Svenska Ventenk. Akad. 4: 1-380

Hariot, M. P. (1909). Sur la croissance des Fucus. C. R. hebd. Séanc. Acad. Sci., Paris 149: 352-354

Hatton, H. (1932). Quelques observations sur le repeuplement en Fucus vesiculosus des surfaces rocheuses denudees. Bull. Lab. marit. Saint-Servan 9: 1-6

Johnson, D. S., Skutch, A. F. (1928a). Littoral vegetation on a headland of Mt. Desert Island, Maine. I. Submersible or strictly littoral vegetation. Ecology 9: 188-215

Johnson, D. S., Skutch, A. F. (1928b). Littoral vegetation on a headland of Mt. Desert Island, Maine. II. Tide-pools and the environment and classification of submersible plant communities. Ecology 9: 307-337

Jones, N. S. (1948). Observations and experiments on the biology of Patella vulgata at Port St. Mary, Isle of Man. Proc. Trans. Liverpool biol. Soc. 56: 60-77

Kemp, A. F. (1862). On the shore zones and limits of marine plants on the north eastern coast of the United States. Can. Nat. $7: 20-34$

Keser, M. (1978). Ecological effects of harvesting on the growth of Ascophyllum and the growth dynamics of Fucus. Ph. D. Dissertation, University of Maine, Orono

Keser, M., Vadas, R. L., Larson, B. R. (1981). Regrowth of Ascophyllum nodosum and Fucus vesiculosus under various harvesting regimes in Maine, USA. Botanica mar. 24: 29-38

Knight, M., Parke, M. W. (1950). A biological study of Fucus vesiculosus $L$. and $F$. serratus L. J. mar. biol. Ass. U. K. 29: 439-514

Lamb, M., Zimmermann, M. H. (1964). Marine vegetation of Cape Ann, Essex County, Massachusetts. Rhodora 66 $217-254$

Lemoine, P. (1913). Quelques experiences sur la croissance des algues marines a Roscoff. Bull. Inst. océanogr. Monaco 277: $1-19$

Lodge, S. M. (1948). Algal growth in the absence of Patella on an experimental strip of foreshore, Port St. Mary, Isle of Man. Proc. Trans. Liverpool biol. Soc. 56: 78-85

Lubchenco, J. (1978). Plant species diversity in a marine intertidal community: importance of herbivore food preference and algal competitive abilities. Am. Nat. 112: 23-39

Lubchenco, J. (1980). Algal zonation in the New England rocky intertidal community: an experimental analysis. Ecology 61: 333-344

Lund, S. (1936). On the production of matter and the growth in some benthic plants. Rep. Dan. Biol. Stn 41: 37-52

MacFarlane, C. (1953). A survey of certain seaweeds of commercial importance in Southwest Nova Scotia. Proceedings of the International Seaweed Symposium, Vol. 1, p. $72-73$

Mathieson, A. C., Hehre, E. J. (1982). The composition sea- 
sonal occurrence and reproductive periodicity of Phaeophyceae (brown algae) of New Hampshire. Rhodora 84: 411-437

Mathieson, A. C., Reynolds, N. B., Hehre, E. J. (1981). Investigations of New England marine algae II: the species composition, distribution and zonation of seaweeds in the Great Bay estuary system and the adjacent open coast of New Hampshire. Botanica mar. 24: 533-545

Mathieson, A. C., Shipman, J. W., O'Shea, J. R., Hasevlat, R. C. (1976). Seasonal growth and reproduction of estuarine fucoid algae in New England. J. exp. mar. Biol. Ecol. 25: 273-284

Moore, H. B. (1939). The colonization of a new rocky shore at Plymouth. J. Anim. Ecol. 8: 29-38

Munda, I. (1964). The quantity and chemical composition of Ascophyllum nodosum (L.) Le Jol. along the coast between the rivers Olfusa and Thjorsa (Southern Iceland). Botanica mar. 7: 76-89

Niemeck, R. A., Mathieson, A. C. (1976). An ecological study of Fucus spiralis L. J. exp. mar. Biol. Ecol. 24: 33-48

Nienburg, W. (1930). Die Besiedelung des Felsstrandes und der Klippen von Helgoland. Teil II. Die Algen. Wiss. Meeresunters., Helgoland, N. F. Bd. 15, No. 19: 1-15

NUSCo (1981). Rocky Shore. In: 1980 Annual report on ecological and hydrographic studies at the Millstone Nuclear Power Station. Northeast Utilities Service Company, Waterford, CT, p. 1-39

Powell, H. T. (1957). Studies in the genus Fucus L. I. Fucus distichus L. emend. Powell. J. mar. biol. Ass, U.K. 36; $407-432$

Powell, H. T. (1963). Speciation in the genus Fucus L., and related genera. In: Harding, J. P., Trebble, N. (ed.) Speciation in the sea, System. Ass. Pub., No. 5: 67-77

Printz, H. (1956). Recuperation and recolonization in Ascophyllum. Proceedings of the International Seaweed Symposium, Vol. 2, p. 194-197

Printz, H. (1959). Phenological studies of marine algae along the Norwegian coast. II. Fucus vesiculosus L. Avhandl. utgitt av Det Norske Videnskaps-Akademi i Oslo. I. Mat.Naturv. Klasse. 4: 17-28

Rees, T. K. (1932). A note on the longevity of certain species of the Fucaceae. Ann. Bot. 46: 1062-1064

Schonbeck, M. W., Norton, T. A. (1978). Factors controlling the upper limits of fucoid algae on the shore. J. exp. mar. Biol. Ecol. 31: 303-313
Southward, A. J. (1953). The ecology of some rocky shores in the south of the isle of Man. Proc. Liverpool Biol. Stn 59: $1-50$

Southward, A. J. (1956). The population balance between limpets and seaweeds on wave beaten rocky shores. Rep. Mar. Biol. Stn, Port Erin 68: 20-29

Southward, A. J. (1964). Limpet grazing and the control of vegetation on rocky shores. In: Crisp, D. J. (ed.) Grazing in terrestrial and marine environments. Blackwell, Oxford, p. $265-273$

Southward, A. J. (1979). Cyclic fluctuations in population density during eleven years recolonization of rocky shores in West Cornwall following the 'Torrey Canyon' oil-spill in 1967. In: Naylor, E., Hartnoll, R. G. (ed.) Cyclic phenomena in marine plants and animals. Pergamon Press, Oxford, New York, p. 85-92

Southward, A. J., Southward, E. C. (1978). Recolonization of rocky shores in Cornwall after use of toxic dispersants to clean up the 'Torrey Canyon' spill. J. Fish. Res. Bd Can. 35: $682-706$

Subrahmanyan, R. (1961). Ecological studies on the Fucales. J. Ind. Bot. Soc. $40 ; 335-354$

Sundene, O. (1973). Growth and reproduction in Ascophyllum nodosum (Phaeophyceae). Norw. J. Bot. 20: 249-255

Taylor, W. R. (1957). Marine algae of the northeastern coast of North America (2nd ed.). University of Michigan Press, Ann Arbor

Topinka, J. A., Tucker, L., Korjeff, W. (1981). The distribution of fucoid macroalgal biomass along central coastal Maine. Botanica mar, 24: 311-319

Vadas, R. L., Keser, M., Larson, B. (1978). Effects of reduced temperatures on previously stressed populations of an intertidal alga. In: Thorpe, J. H., Gibbons, J. W. (ed.) Energy and environmental stress in aquatic systems, DOE Symposium Series (Conf-771114, NTIS), Springfield, Virginia, p. $434-451$

Vadas, R. L., Keser, M., Rusanowski, P. C. (1976). Influence of thermal loading on the ecology of intertidal algae. In: Esch, G., MacFarlane, R. (ed.) Thermal ecology II, AEC Symposium Series (Conf-750425), August, Georgia, p. 202-212

Walker, F. T. (1947). A seaweed survey of Scotland-Fucaceae. Proc. Linn. Soc. Lond. 159: 90-99 